Volume 2 No. 1, Juni 2017

P ISSN 2442-594X | E ISSN 2579-5708

http://journal.iainlangsa.ac.id/index.php/tibyan

\title{
TAFSIR TEMATIK TENTANG SELEKSI INFORMASI
}

\section{Thematic's Tafseer About Information's Selection}

\author{
Mawardi Siregar \\ Institut Agama Islam Negeri Langsa \\ sipirokpbujur $7 \overline{6} g m a i l . c o m$
}

\begin{abstract}
This article discusses about how a person behaves when receiving information that comes from trusted people or those who are not trusted. Islam, explains to every Muslim to be selective in receiving information. This selectivity needs to be done to avoid undesirable things. Because errors in receiving information can have a fatal effect on social life. Selective means checking and recharging both the news source and the news delivered, so that the information received is accurate in accordance with the actual conditions.
\end{abstract}

Keywods: Thematic's Tafseer, selectivity, information

\begin{abstract}
Abstrak
Tulisan ini membahas tentang bagaimana sikap seseorang pada saat menerima sebuah informasi yang datang dari orang terpercaya maupun yang tidak dipercaya. Islam, menjelaskan kepada setiap muslim untuk selektif dalam menerima informasi. Selektifitas tersebut perlu dilakukan untuk menghindari hal-hal yang tidak diinginkan. Sebab kesalahan dalam menerima informasi, dapat memberikan efek yang fatal terhadap kehidupan sosial kemasyarakatan. Selektif berarti melakukan check and recheck baik terhadap sumber berita maupun terhadap berita yang disampaikan, sehingga informasi yang diterima akurat sesuai dengan kondisi yang sebenarnya.
\end{abstract}

Kata Kunci:Tafsir tematik, selektifitas, informasi

\section{Pendahuluan}

Ayat Alquran memberi pedoman dan tuntunan pada manusia dalam berbagai aspek, misalnya politik, ekonomi, sosial, budaya, dan lain-lain. Salah satu tuntunan yang dibahas oleh Alquran adalah selektif dalam menerima dan menyampaikan informasi. Atmosfer perubahan yang didorong oleh kemajuan teknologi informasi yang 
terus berkembang, memaksa setiap manusia untuk menggunakannya sebagai media untuk mendapatkan berbagai macam informasi. Oleh karena itu, masyarakat harus cerdas dan selektif serta kritis dalam menerima setiap informasi. Dalam bahasa Alquran, sikap selektif dan kritis tersebut diistilahkan dengan tabayyun. Perintah tabayyun ini semakin penting, ketika fenomena perpecahan umat yang disebabkan prasangka semakin menguat. Perpecahan tidak hanya terjadi dikalangan umat beragama, tetapi terjadi juga dikalangan umat seagama. Belakangan ini, orang atau suatu kelompok sangat mudah berprasangka negatif terhadap kelompok lain atau menuduh sesat golongan lain, dan kadang disertai hujatan, penghakiman secara sepihak, akibat ketidakselektifan dan ketidakkritisan dalam menelaah suatu informasi.

Dalam kaitan itu, Alquran mengharuskan setiap orang untuk bersikap selektif dan hati-hati (tabayyun) dalam menerima informasi. Setiap orang harus mencari bukti terkait dengan isu yang berkembang, agar terhindar dari sikap apriori yang berujung pada penyalahan, penghujatan dan penghakiman secara sepihak. Konkritnya, perintah selektifatau kritis (tabayyun) terhadap suatu informasi, merupakan peringatan agar setiap orang tidak sampai tergesa-gesa menuduh orang lain dengan sesuatu yang tidak benar. Tabayyun merupakan seperangkat moral ideal dalam menjaga nilai-nilai kemanusiaan global. Atas dasar itu, kajian akademik tentang konsep tabayyun ini menjadi penting untuk didiskusikan. Paling tidak, kajian ini diharapkan dapat memberikan kontribusi terhadap praktik komunikasi Islam sehari-hari di tengah perubahan masyarakat yang bersifat mondial.

Artikel ini fokus membahas tentang konsep tabayyun dalam Alquran. Secara khusus ayat yang dikaji merujuk ke dalam surah Al Hujurāt ayat 6. ${ }^{1}$ Ayat ini akan dikaji dari sudut pandang tafsir tematik, dengan mengumpulkan tema-tema penting yang berkaitan dengan praktik komunikasi. Tema-tema tersebut dianalisis untuk melihatketerkaitan masa lampau, masa kini dan masa mendatang. Untuk meruntutkan pembahasan, pendahuluan ini akan segera disusul oleh pembahasan terkait, yang dimulai dari ayat yang berkaitan dengan tabayyun, sebab turunnya ayat (asbabun nuzul), tafsir ayat, munasabah ayat, aspek pentingnya tabayyun dalam praktik komunikasi.

\section{Informasi; Suatu Konsep Dasar}

\footnotetext{
${ }^{1}$ Bila ditelaah secara umum, surah Al Hujurāt mengandung pesan-pesan moral kemasyarakatan. Nilai-nilai dan pesan moral yang ada dalam surah Al Hujurät antara lain adalah menyuruh agar melakukan tabayyun (klarifikasi) terhadap informasi, islah (perdamaian), ukhuwah (persaudaraan), ta'aruf (saling mengenal), musawah (persamaan derajat). Surah ini juga banyak mengandung makna larangan, seperti tidak mendahului Allah dan Rasul-Nya, tidak meninggikan suara, tidak mengolok-olok, tidak berprasangka buruk, tidak mencari-cari keburukan dan tidak mengunjing. Semua nilai-nilai tersebut merupakan pondasi penting dalam membangun tatanan masyarakat yang berkeadaban. Sebagaimana disebutkan Sayyid Qutb, bahwa surah Al Hujurāt merupakan salah satu dari beberapa surah yang intens dan fokus membahas tentang aspek akhlak dan pergaulan hidup manusia. Lihat, Sayyid Quthb, Tafsir Fị Zilālil Qur'ān, Juz 10, terj. As’ad Yasin, dkk (Jakarta: Gema Insani, 2009), h. 406.
} 
Informasi merupakan istilah yang lazim terdengar dalam kehidupan sehari-hari. Selain menerima informasi, kita dapat menyebarkan informasi dengan mudah ke seluruh dunia. Mulai dari bangun tidur sampai tidur kembali kita selalu berhubungan dengan informasi. Terutama dalam era keterbukaan yang disebut dengan open sky (langit terbuka) istilah informasi merupakan konsumsi yang akrab dengan keseharian manusia. Pada zaman sekarang dimana dunia sudah tidak ada batasan lagi kita dapat dengan mudah mengakses informasi apa saja. Dengan telepon pintar yang hanya mengandalkan sentuhan jari kita dapat dengan mudah mengetahui apa yang sedang terjadi di negara lain yang sangat jauh jaraknya. Fenomena ini disebut McLuhan dengan istilah global village (desa global).

Informasi merupakan data yang berasal dari fakta yang tercatat dan selanjutnya dilakukan pengolahan (proses) menjadi bentuk yang berguna atau bermanfaat bagi pemakainya. Konretnya, informasi secara sederhana adalah hasil dari kegiatan pengolahan data yang memberikan bentuk lebih berarti dari suatu kejadian. Menurut Davis, sebagaimana dikutip Abdul Kadir, informasi adalah data yang telah diolah menjadi sebuah bentuk yang berarti bagi penerimanya dan bermanfaat bagi pengambilan keputusan saat ini atau saat mendatang. ${ }^{2}$

Dengan demikian, informasi merupakan kumpulan data yang diolah menjadi bentuk yang lebih berguna dan lebih berarti bagi yang menerima. Artinya, informasi merupakan hasil kesaksian atau rekaman peristiwa atau data yang berasal dari fakta yang tercatat dan selanjutnya dilakukan pengolahan (proses) menjadi bentuk yang berguna dan berarti bagi pemakainya yang pada akhirnya akan mempengaruhi kehidupan pemakai informasi. Dari sini juga dipahami, bahwa informasi memberikan manfaat dalam menambah pengetahuan, dapat memberikan standar dalam menetapkan keputusan di masa yang akan datang.

Informasi yang disampaikan para pakar, memiliki perbedaan dari berbagai aspeknya, cirinya, bahkan manfaatnya. Namun demikian, satu hal yang perlu dipahami bahwa informasi tentu sangat banyak manfaatnya bagi setiap orang. Sebagaimana dijelaskan Sutanta, bahwa paling tidak ada lima manfaat informasi, yaitu:

a. Menambah pengetahuan. Dengan adanya informasi, maka akan dapat memberikan tambahan pengetahuan bagi penerima yang dapat digunakan sebagai bahan pertimbangan yang mendukung proses pengambilan keputusan.

b. Mengurangi ketidakpastian pemakai informasi. Informasi akan mengurangi ketidakpastian karena apa yang akan terjadi dapat diketahui sebelumnya, sehingga kemungkinan menghindari keraguan pada saat pengambilan keputusan.

c. Mengurangi resiko kegagalan. Adanya informasi akan mengurangi resiko kegagalan karena apa yang akan terjadi dapat diantisipasi dengan baik, sehingga kemungkinan terjadinya kegagalan akan dapat dikurangi dengan pengambilan keputusan yang tepat.

\footnotetext{
${ }^{2}$ Abdul Kadir, Pengenalan Sistem Informasi (Yogyakarta: Andi, 2003), h. 28.
} 
d. Mengurangi keanekaragaman yang tidak diperlukan. Mengurangi keanekaragaman yang tidak diperlukan akan menghasilkan keputusan yang lebih terarah.

e. Memberikan standar, aturan-aturan, ukuran-ukuran, dan keputusan untuk menentukan pencapaian, sasaran dan tujuan. ${ }^{3}$

Lima manfaat yang dijelaskan di atas, paling tidak memberikan pemahaman bahwa informasi akan memberikan pengetahuan tentang aturan dan keputusan yang lebih terarah untuk mencapai sasaran dan tujuan yang telah ditetapkan secara lebih baik berdasarkan informasi yang diperoleh. Informasi juga dapat mengurangi ketidakpastian dan menambah pengetahuan dan wawasan. Informasi dapat dicari dari berbagai sumber, seperti di perpustakaan, dari lembaga, dari buku, dari tokoh dan sebagainya. Tidak ada seorang pun yang tidak membutuhkan informasi, apapun jenis pekerjaannya. Pelajar, mahasiswa, guru, dosen,semuamemerlukan informasi guna mendukung pekerjaannyasehari-hari. Persoalannya, tingkat pencarian informasi sangat tergantung kepada kebutuhan orang yang bersangkutan. Kebutuhan terhadap informasi muncul akibat kesenjangan pengetahuan yang ada dalam diri seseorang dengan kebutuhan informasi yang diperlukan. Bila diperhatikan, faktor paling umum yang mempengaruhi kebutuhan seseorang terhadap informasi adalah karena faktor pekerjaan, kebiasaan dan lingkungan sekitar yang mendukung terhadap pentingnya informasi tersebut.

Menurut Wilson, ada beberapa faktor yang mempengaruhi bagaimana akhirnya seseorang mewujudkan kebutuhan informasi dalam bentuk perilaku informasi yaitu:

a. Kondisi psikologis seseorang. Dalam kaitan ini, seseorang yang sedang risau akan memperlihatkan perilaku informasi yang berbeda dibandingkan dengan seseorang yang sedang gembira. Maka kondisi psikologis ini merupakan faktor yang menyebabkan seseorang untuk melakukan pencarian informasi.

b. Demografis. Dalam arti luas menyangkut kondisi sosial-budaya seseorang sebagai bagian dari masyarakat tempat ia hidup berkegiatan. Kita dapat menduga bahwa kelas sosial juga dapat mempengaruhi perilaku informasi seseorang, walau mungkin pengaruh tersebut lebih banyak ditentukan oleh akses seseorang ke media perantara. Perilaku seseorang dari kelompok masyarakat yang tak memiliki akses ke internet pastilah berbeda dari orang yang hidup dalam fasilitas teknologi melimpah.

c. Peran seseorang di masyarakatnya. Khususnya dalam hubungan interpersonal, ikut mempengaruhi perilaku informasi. Misalnya, peran menggurui yang ada di kalangan dosen akan menyebabkan perilaku informasi berbeda dibandingkan perilaku mahasiswa yang lebih banyak berperan sebagai pelajar. Jika kedua orang ini berhadapan dengan pustakawan, peran-peran mereka akan ikut mempengaruhi cara mereka bertanya, bersikap, dan bertindak dalam kegiatan mencari informasi.

${ }^{3}$ Edhy Sutanta, Sistem Informasi Manajemen (Yogyakarta: Graha Ilmu, 2003), h. 11. 
d. Lingkungan. Dalam hal ini adalah lingkungan terdekat maupun lingkungan yang lebih luas.

e. Karakteristik sumber informasi. Karakter media yang akan digunakan dalam mencari dan menemukan informasi.

Kelima faktor di atas menurut Wilson akan sangat mempengaruhi perilaku seseorang dalam mewujudkan kebutuhan terhadap informasi. Kebutuhan terhadap informasi sangat erat kaitannya dengan perilaku informasi, yaitu suatu perilaku manusia yang berkaitan dengan sumber dan saluran informasi, termasuk perilaku penemuan dan penggunaan informasi baik secara aktif maupun secara pasif. Sepanjang manusia memerlukan informasi, maka manusia akan terus bertindak untuk memenuhi kebutuhan informasinya tersebut. Perilaku pencarian informasi adalah kegiatan dalam menentukan dan mengidentifikasikan pesan untuk memuaskan kebutuhan informasi yang dirasakan. Menurut Wilson, perilaku pencarian informasi adalah:

Information searching behavior is the 'micro-level' of behavior employed by the searcher in interacting with information systems of all kinds. It consists of all the interactions with the system, wheter at the level of human computer interaction (for example, use of the mouse and clicks on links) or at the intellectual level (for exmple, adopting a boolean search strategy or determining the criteria for deciding which of two books selected from adjacent places on a library shelf is most useful), which will also involve mental acts, such as judging the relevance of data or information retrieved. ${ }^{4}$

Information searching behaviour adalah perilaku pencarian informasi ditingkat mikro yang digunakan pencari ketika berinteraksi dengan sistem informasi. Dengan demikian, dapat disimpulkan bahwa perilaku pencarian informasi merupakan tindakan yang dilakukan untuk mencari, mengumpulkan dan memakai informasi yang dibutuhkan oleh pengguna baik yang berkaitan dengan pekerjaan, tugas, maupun kepentingan pribadi atau kelompok. Wilson juga menjelaskan model pencarian informasi

Gambar 1. Model Teori Perilaku Informasi oleh Wilson.

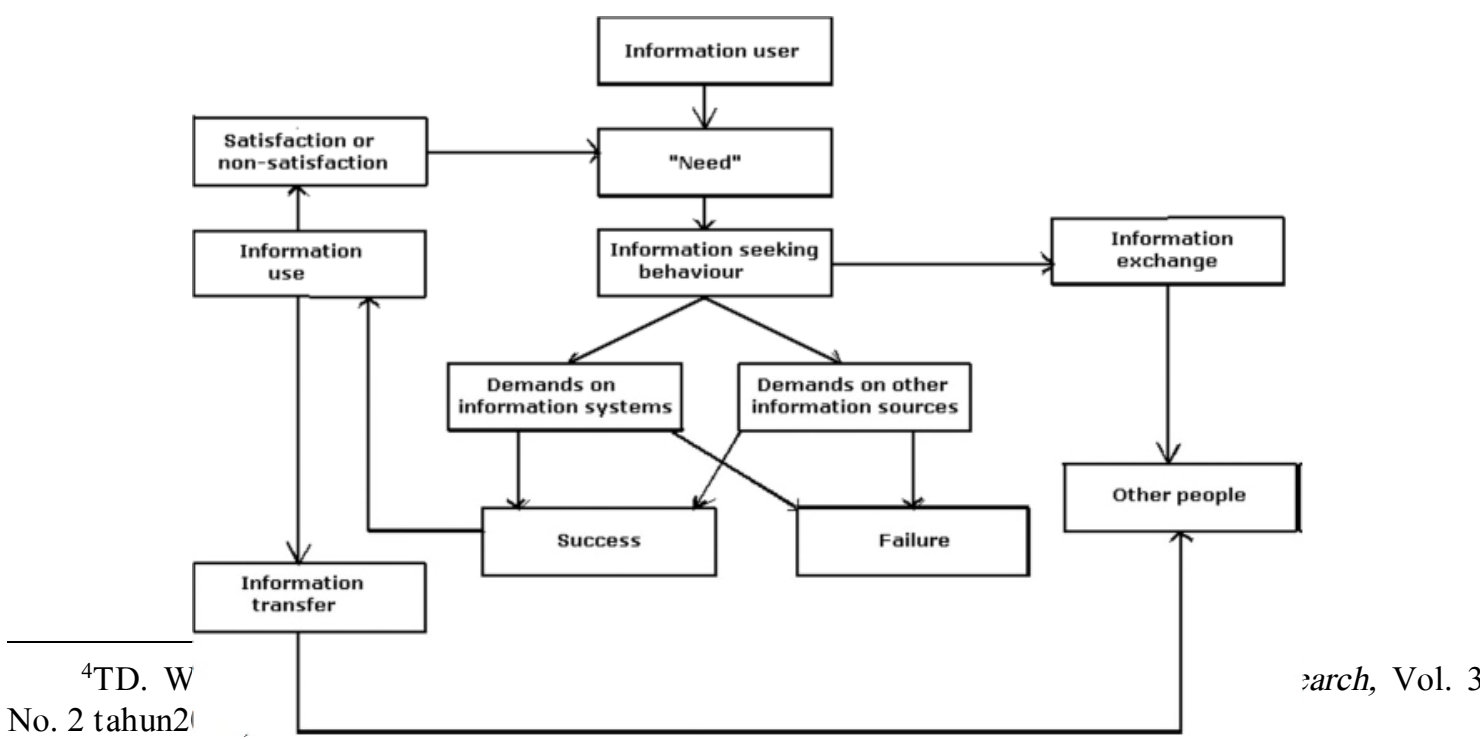


Model di atas menjelaskan bahwa pengguna informasi ada karena kebutuhan informasi, sehingga pencarian informasi pun dilakukan. Informasi dapat dicari di sistem informasi maupun sumber yang lainnya. Apabila pencarian sukses dan memuaskan pengguna, maka informasi tersebut akan diteruskan ke orang lain. Model ini menunjukkan bahwa perilaku pencarian informasi melibatkan orang lain untuk pertukaran informasi dan informasi tersebut digunakan untuk kepentingan sendiri maupun orang lain.

\section{Ayat Berkaitan dengan Seleksi Informasi (Tabayyun)}

Islam mengatur kehidupan manusia, termasuk sistem komunikasi sosial yang berlangsung di masyarakat. Islam menyerukan agar melakukan pengecekan atau pengklarifikasian terhadap setiap berita, supaya terhindar dari kesalahpahaman. Sebab banyak fitnah yang muncul disebabkan kesimpangsiuran informasi yang berkembang. Hal ini ditegaskan dalam surah Al Hujurāt [49]: 6 yang berbunyi;

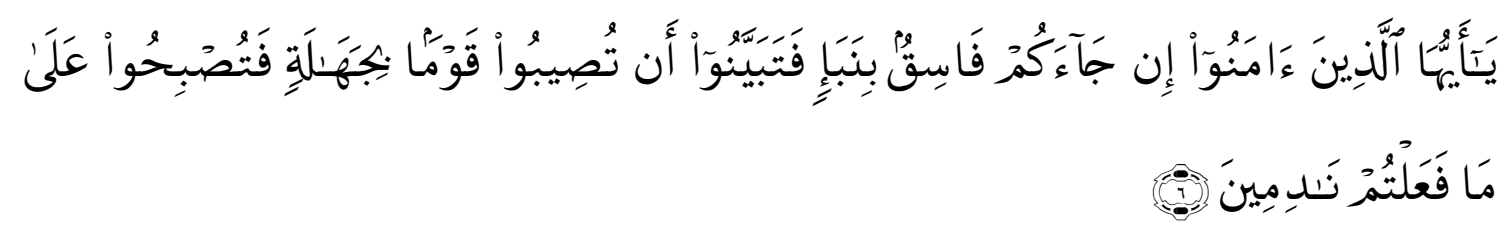

Artinya: "Hai orang-orang yang beriman, jika datang kepadamu orang fasik membawa suatu berita, Maka periksalah dengan teliti agar kamu tidak menimpakan suatu musibah kepada suatu kaum tanpa mengetahui keadaannya yang menyebabkan kamu menyesal atas perbuatanmu itu." (QS. Al-Hujarāt [49] : 6)

Kata tabayyun adalah bahasa Arab yang diderivasi dari akar kata tabayyana yatabayyanu - tabayyunan.Artinya adalah mencari kejelasan hakekat suatu fakta dan informasi atau kebenaran suatu fakta dan informasi dengan teliti, seksama dan hatihati, sehingga jelas benar keadaannya. Dalam Kamus Besar Bahasa Indonesia, tabayyun diartikan sebagai pemahaman atau penjelasan. Dengan demikian, tabayyun adalah usaha untuk memastikan dan mencari kebenaran dari sebuah informasi, sehingga informasi tersebut dapat dipertanggungjawabkan. Konkritnya, tabayyun dipahami sebagai sikap ketelitian dan selektifitas dalam menerima suatu berita, tidak tergesa-gesa dalam menilai dan memutuskannya sampai jelas kebenarannya. Dengan demikian, tabayyun adalah salah satu akhlak mulia yang merupakan prinsip penting dalam menata keharmonisan pergaulan dalam kehidupan sehari-hari.

Pada ayat 6 surah al-Hujurāt dijumpai kalimat fatabayyanu, yang diartikan dengan periksalah dengan teliti. Maksudnya bahwa suatu berita perlu diteliti dengan cermat, sehingga menghasilkan informasi yang benar dan akurat. Ibnul Qoyyim alJauziyyah dalam hal ini menegaskan, bahwa Allah swt tidak memerintahkan menolak berita dari orang fasiq dan tidak pula menerimanya begitu saja. Kehati-hatian menjadi hal yang mutlak dalam menerima satu informasi. Setalah ditelaah secara kritis, jika adatanda dan bukti bahwa berita yang disampaikan benar, maka boleh mempercayai informasi tersebut, sekalipun yang menyampaikan itu orang fasiq. 


\section{Sebab Turunnya Ayat (Asbābun Nuzūi)}

Suratal-Ḥjurāt diturunkan setelah Fatḥu Makkah (penaklukan kota Makkah). Adalah al-Haris bin Dirar masuk Islam dan berikrar akan mengajak kaumnya masuh Islam dan menunaikan zakat. Setelah al-Haris kembali ke kaumnya, dan ia mengumpulkan zakat dari orang-orang yang menerima seruannya masuk Islam, dan waktu yang ditetapkan untuk dikirim kepada Rasulullah saw. pun telah tiba, tiba-tiba utusan yang akan mengambil itu tertahan, tidak bisa datang, sehingga al-Harï menduga terjadi sesuatu hal yang menyebabkan Allah dan Rasul-Nya marah. Akibat dugaan itu, al-Haris kemudian memanggil tokoh-tokoh kaumnya seraya berkata pada mereka: Rasulullah saw memberikan waktu kepadaku, bahwa utusannya akan datang ketempat kita buat mengambil harta zakat, dan Rasulullah tidak mungkin bedusta, sedang aku yakin, bahwa tertahannya utusan itu pasti karena Allah dan Rasul-Nya murka kepadaku. Oleh karena itu marilah kita pergi bersama-sama ketempat Rasulullah saw. ${ }^{5}$

Sebenarnya dugaan itu salah, karena secara historis, dalam berbagai tafsir disebutkan bahwa Rasulullah saw mengutus al-Walid bin 'Uqbah ke tempat al Haris untuk mengambil zakat yang telah dikumpulkannya. Tetapi setelah al-Walid pergi, tiba-tiba di tengah jalan ia merasa takut lalu kembali. Dalam keterangannya kepada Rasulullah swa, al-Walid mengatakan bahwa ia kembali karena dia dihalang-halangi oleh al-Haris untuk memungut zakat tersebut, dan dia diancam akan dibunuh. Lalu Rasulullah saw. marah dan mengirimkan pasukan tempur ketempat al Haris. Di tengah perjalanan, pasukan ini bertemu dengan golongan al Haris yang tadi telah bergerak meninggalkan tempatnya. Mereka mengatakan: Ini kan Haris. Haris pun kemudianbertanya: "Kalian hendak kemana?" Mereka menja-wab: "Ke tempatmu". Haris bertanya lagi: "Untuk keperluan apa"? Mereka menjawab: "Nabi saw telah mengutus al-Walid bin "Uqbah ketempatmu untuk mengambil zakat yang engkau himpun, tetapi dia merasa bahwa engkau menghalanginya, bahkan engkau hendak membunuhnya”. Maka jawab al-Haris: "Tidak, demi Dzat yang mengutus Muhammad dengan benar, sungguh aku tidak melihat al-Walid dan ia pun tidak pernah datang ketempatku. Setelah Haris masuk ke tempat Nabi saw, beliau pun segera bertanya: "Betul engkau telah menghalang-halangi al-Walid untuk memungut zakat dan engkau hendak membunhnya?" Haris menjawab: “Tidak, demi Dzat yang mengutusmu dengan benar, aku tidak melihatnya dan ia pun tidak pernah datang ketempatku. Kini aku datang adalah karena utusanmu itu tidak datang ketempatku, dan aku khawatir kalaukalau hal itu memang karena murka Allah dan Rasul-Nya kepadaku". ${ }^{6}$

Berkaitan dengan kasus tersebut, maka turunlah ayat 6 surah al-Ḥujurāt, sebagai peringatan bagi setiap mukmin, agar tidak hanya menerima keterangan dari sebelah pihak. Dalam konteks ayat tersebut, informasi yang diberedar sangat penting di cek

\footnotetext{
${ }^{5}$ Aṭ-Tabarì, Jāmi' al-Bayān 'an Ta’wīl al-Qur'ān Juz XXVI (Beirūt: Dār al-Fikr, 1405), h. 123-124.

${ }^{6}$ Salah satu tafsir yang menjelaskan prihal kejadian ini terdapat dalam, Muhammad ATi Aṣ Șabūni, Terjemah Tafsir Aḥkām (Surabaya: PT Bina Ilmu, 1987), h. 104.
} 
kembali kebenarannya. Penerimaan terhadap informasi sepihak, akan menyebabkan munculnya kesenjangan informasi yang berakibat terjadinya kesalahpahaman. informasi yang tidak akurat dapat mengakibatkan munculnya keputusan yang tidak tepat, sehingga dapat memunculkan kezaliman di tengah masyarakat.

\section{Tafsir Ayat}

Surah al-Hujurāt ayat 6 turun memberikan penjelasan bagi umat manusia semuanya untuk selalu korektif, selektif dan kritis (tabayyun) terhadap segala berita yang disampaikan oleh orang muslim maupun non muslim. Kemudian ayat ini menyuruh berhati-hati dalam menindakkan sesuatu yang akibatnya tidak dapat diperbaiki, misalnya perkataan yang sesungguhnya banyak menimbulkan perpecahan, kerugian, karena berita yang disampaikan belum pasti kebenarannya. Surah Al Hujurăt ayat 6 dimulai dengan kalmiat yā ayyuhallażina $\bar{a} m a n \bar{u}$, yaitu suatu kata panggilan (nidā') yang diserukan kepada orang-orang yang beriman. Kalimat seruan biasanya digunakan dalam rangka memulai percakapan, agar orang yang diseru memperhatikan dengan serius pesan yang akan disampaikan, karena sesudah panggilan, biasanya ada hal-hal penting yang harus diperhatikan. Dalam konteks ini, orang-orang beriman diseru berhati-hati pada saat menerima informasi ketika ada orang fasik membawa berita kepadanya, dan tidak mempercayainya secara langsung.

Dalamkontekssurahal-Ḥjurātayat 6,Allah mengguna-kan jumlah syarțiyyah (kalimat bersyarat), in jā'akum fásiqun (jika datang orang fasik membawa berita kepadamu), dengan fáil (subyek) yang berbentuk sifat, fásiqun (orang fasiq). Ini merupakan isyarat yang lembut, bahwa seorang mukmin haruslah benar-benar sadar, jangan mudah menerima informasi sebelum diketahui terlebih dahulu sumbernya. Kata fāsiq berarti al-khurūj min al-ța' 'ah (keluar dari ketaatan). Menurut as-Syawkānī, fasik dalam konteks ayat ini adalah dusta atau bohong. ${ }^{7}$ Dalam kitab Safwăt al-Tafäsìr juga dijelaskan bahwa yangdimaksud fásiq adalah orang yang tidak dapat dipercayai, tidak dapat diyakini kejujuran dan keadilannya. ${ }^{8}$

Kata fäsiq disebutkan di atas dengan bentuk nakirah (tanpa alif-lām) untuk menunjukkan umum. Karena bentuk nakirah dalam konteks syarat adalah sama dengan nakirah dalam konteks nafi, yaitu menunjukkan umum. Jadi, maksud kalimat tersebut ialah siapa saja orang munafiq yang datang kepadamu baik dari kalangan muslim maupun non muslim, sahabat atau tidak sahabat. Disitu digunakan kata "in" (jika) yang menunjukkan keragu-raguan (tasykikk), bukan kata iżà (apabila) yang menunjukkan kepastian (tahqīq), meskipun kata iżā juga memberi isyarat. Sebab prinsip seorang mukmin haruslah jujur apalagi mereka adalah seorang sahabat, tent unya mempunyai keimanan yang lebih tinggi daripada generasi penerusnya. Secara historis juga terlihat dengan jelas, bahwa yang melakukan perbuatan fasiq dalam ayat tersebut adalah orang muslim dan sekaligus seorang sahabat nabi. Hal ini sebenarnya

\footnotetext{
${ }^{7}$ Al-Syawkānī, Fath al-QadirJuz V (Beirut: Dar al-Fikr, tt), h. 60.

${ }^{8}$ Muhammad 'Ali Al-Ṣabūnī, Șafwăt al-Tafāsīr, Jilid III (Bairut: Maktabat al Aṣriyah, 2011), h. 1202.
} 
sangat jarang terjadi. Oleh sebab itu, dari sini dipahami bahwa tidak ada jaminan bahwa jika seseorang telah memeluk agama Islam, lalu kemudian ia akan berlaku baik dalam segala aspek kehidupan.

Penggunaan kata nabā' (berita) berbeda dengan kata khabara yang artinya samasama berita atau informasi. Menurut Quraish Syihab, dalam ayat ini digunakan kata nabā' yang mempunyai konotasi bahwa berita tersebut adalah berita penting, bukan sekadar berita biasa. Demikian juga pembawa informasinya, dipercaya atau tidak dipercaya. ${ }^{9}$ Menurut ar-Rāgib al-Așfaḥāni, berita pada dasarnya tidak disebut nabā', sampai mempunyai faedah besar, yang bisa menghasilkan keyakinan atau galabat at zān (dugaan kuat). Di sisi lain, kata naba’ tersebut merupakan bentuk nakïrah (umum), yang berarti meliputi semua jenis dan bentuk berita, baik ekonomi, politik, pemerintahan, sosial, pendidikan dan sebagainya. Al-Manawi sebagaimana dikutip Harjani Hefni, juga menegaskan bahwa yang dimaksud nabā' adalah khabar yang memiliki manfaat yang besar, menghasilkan kualitas berita sampai derajat ilmu (akurat) atau ghalābat al-z̧an(kemungkinan benarnya lebih besar). Sifat nabā' menurut al-Manawi adalah bebas dari informasi yang mengandung dusta. ${ }^{10}$

Dari beberapa penjelasan yang diuraikan di atas, dapat dipahami bahwa kata nabā' secara umum berarti berita yang memiliki tingkat akurasi yang tinggi atau paling tidak tingkat kebenarannya lebih diyakini daripada tingkat kekeliruannya. Tetapi dalam konteks ini perlu diperhatikan, jika yang menyampaikan informasi adalah Allah swt (Wahyu) dan Rasul (Hadis), tentu tidak diragukan kebenarannya. Sebaliknya, jika yang menyampaikan berita adalah manusia (manusia biasa), apalagi orang pembawa berita adalah fasik, apapun jenis dan bentuk informasinya, maka tingkat kebenaran informasi itulah sesungguhnya yang perlu diperiksa. Konkritnya, kata nabā' dapat dimaknai sebagai berita yang memiliki dampak yang luas, tidak hanya bagi individu, tetapi bagi seluruh aspek kehidupan, sehingga kuat tuntutan bagi seseorang, untuk menyimak, menelaah dan mengklarifikasinya (tabayyun), sebelum memutuskannya.

Kata tabayyan menurut al-Syawkāni, berarti at-ta'arruf wa tafaḥ̣uṣ (mengindentifikasi dan memeriksa) atau mencermati sesuatu yang terjadi dan berita yang disampaikan. ${ }^{11}$ Ayat di atas merupakan salah satu dasar yang ditetapkan agama dalam kehidupan sosial sekaligus ia merupakan tuntunan yang sangat logis bagi penerimaan dan pengalaman suatu berita. Kehidupan manusia dan interaksinya haruslah didasarkan hal-hal yang diketahui dengan jelas. Manusia sendiri tidak dapat menjangkau seluruh informasi, karena itu ia membutuhkan pihak lain. Pihak lain itu ada yang jujur dan memiliki integritas sehingga hanya menyampaikan hal-hal yang benar, dan ada pula sebaliknya. Karena itu pula berita harus diseleksiagar seseorang melangkah berdasarkan pengetahuan.

\footnotetext{
${ }^{9}$ M. Quraish Shihab, Tafsir Al-Misbah. Volume XIII (Jakarta: Lantera Hati, 2002), h. 238.

${ }^{10}$ Harjani Hefni, Komunikasi Islam (Jakarta: Kencana, 2001), h. 116.

${ }^{11}$ Al-Syawkānī, Fath al-Qadir,h. 60.
} 
An tuṣību qawman bi jậălatin (supaya kalian tidak menjatuhkan keputusan kepada suatu kaum tanpa pengetahuan). Bi jậălatin (dalam kondisi kalian tidak mengetahui) adalah keterangan hal (keadaan yang menjelaskan perbuatan subyek). Menurut al-Ṣabuni, konteks bi jậălatin tersebut sama artinya dengan wa antum jạhilūn (sementara kalian tidak mengetahui)sebuah keterangan yang menjelaskan keadaan subyek ketika membuat keputusan atau kesimpulan. ${ }^{12}$ Keadaan ini umumnya terjadi karena informasi yang digunakan untuk mengambil keputusan atau kesimpulan tersebut tidak dicek terlebih dulu. Fatuṣbiḥu 'ala mā fa' altum nādimīn (sehingga kalian menyesali apa yang telah kalian lakukan). Penyesalan tersebut terjadi tentu karena keputusan yang dijatuhkan sebelumnya ternyata salah, tidak akurat, dan merugikan orang lain termasuk pengambil keputusan.

\section{Munāsabah Ayat}

Munāsabah berarti adanya keserupaan dan kedekatan diantara berbagai ayat, surah dan kalimat yang mengakibatkan adanya hubungan. Hubungan tersebut bisa terkait dengan makna ayat, bisa dalam bentuk penguatan, penafsiran dan penggantian. Dalam kaitannya dengan pembahasan makalah ini, munasabah ayat 6 surah al-Hujurāt ini dapat dilihat dari ayat sebelum dan sesudahnya, yaitu ayat $1-5$ dan ayat $7-8$.

Dapat dipahami bahwa dari sebab turunnya ayat 6 ini adalah berawal dari peristiwa diut usnya al-Walid bin 'Uqbah oleh Rasulullah saw. untuk mengambil zakat ke tempat al-Harï, sebagaimana telah dijelaskan sebelumnya. Konteks ayat ini sesungguhnya tidak hanya berbicara tentang bagaimana layaknya seorang muknim itu dalam menerima informasi yang diragukan kebenarannya. Tetapi dalam ruang yang lebih luas, pesan yang dapat ditangkap dari ayat ini adalah bagaimana idealnya seorang muslim itu menjaga etika dan moral kemasyarakatan. Sebab bila ditelaah ayat sebelumnya, yaitu ayat 1-5, sejumlah ayat ini sebagaimana dijelaskan Ibnu Kasir menjelaskan tentang perbedaan pendapat antara Abu Bakar dan Umat dalam perihal siapa yang seharusnya mengurus kafilah Bani Tamim yang mendatangi Rasulullah saw, karena perbedaan itu, sehingga turunlah ayat tersebut. ${ }^{13}$

Dalam riwayat lain dikemukakan bahwa ayat ini turun karena adanya perbedaan pendapat di antara orang-orang yang menyembelih kurban sebelum waktu yang ditetapkan oleh Rasulullah saw. Maka Rasulullah saw memerintahkan unrtuk berkurban sekali lagi. Ayat pertama surah al-Ḥujurāt turun sebagai larangan kepada kaum mukmin untuk mendahului ketetapan Allah dan Rasul-Nya. ${ }^{14}$ Dalam suatu riwayat dikemukakan bahwa orang-orang berbicara keras dan nyaring ketika berbicara kepada Rasulullah saw. Maka turunlah ayat 2 surah al-Hujurāt sebagai larangan atas perbuatan seperti demikian. Dalam suatu riwayat dikemukakan, apabila orang-orang

\footnotetext{
${ }^{12}$ Al-Ṣabunì, Șafwāt al-Tafāsir, h. 233.

${ }^{13}$ Qamaruddin Shaleh, dkk, Asbābun Nuzul; Latar Belakang Historis Turunnya Ayat-Ayat alQur'an (Bandung: CV. Diponegoro, 2009), h. 510. Lihat juga, Ibnu Katsir, Tafsir Alqurān al-'Ażim Jilid IV (Damaskus: Dār al-Khair, 2006), h. 260.

${ }^{14}$ Qamaruddin Shaleh, dkk, Asbābun Nuzul..., h. 510.
} 
Arab berkunjung kerumah Rasulullah saw. Mereka suka berteriak memanggil beliau dari luar rumah dengan ucapan : "Hai Muhammad! Hai Muhammad" Maka Allah menurunkan ayat 4 sampai 5 surah al-Hujurāt yang menunjukkan perbuatan seperti demikian bukan merupakan akhlak Islam.

\section{PentingnyaTabayyun dalam Praktik Komunikasi dan Pemberitaan}

Komunikasi merupakan salah satu fungsi dari kehidupan manusia. Fungsi komunikasi dalam kehidupan menyangkut banyak aspek. Melalui komunikasi seseorang menyampaikan apa yang ada dalam bentuk pikirannyaatau perasaan hati nuraninya kepada orang lain baik secara langsung ataupun tidak langsung. Melalui komunikasi seseorang dapat membuat dirinya untuk tidak terasing dan terisolir dari lingkungan di sekitarnya. Melalui komunikasi seseorang dapat mengajarkan atau memberitahukan apa yang diketahuinya kepada orang lain. Sarana yang paling banyak digunakan untuk berkomunikasi adalah bahasa, karena dengan bahasalah (lisan atau tulisan), manusia mampu menerjemahkan pikiran seseorang kepada orang lain, baik yang berbentuk ide, informasi atau opini bisa dalam bentuk konkret ataupun abstrak. Hal itu bukan hanya suatu hal atau peristiwa yang sedang terjadi sekarang, tetapi juga pada masa lalu atau waktu yang akan datang.

Kehidupan manusia, termasuk sistem komunikasi sosial yang berlangsung di masyarakat telah diatur secara massif oleh Islam. Termasuk muatan aturan-aturan itu, terdapat dalam surah al-Hujurāt. Surah ini secara keseluruhan membimbing kehidupan bermasyarakat yang Islami. Surah ini mengajarkan sikap yang benar terhadap Rasulullah saw., sikap yang baik terhadap sesama mukmin, dan juga mengajarkan kewajiban dan tanggung jawab terhadap masyarakat Islam. Petunjuk-petunjuk tersebut bertujuan untuk menjaga dan memelihara keutuhan masyarakat Islam, dijauhkan dari kecerobohan internal umat Islam yang membahayakan masyarakat Islam. Salah satu faktor yang menjadi landasan penting dalam surah ini adalah sikap ideal seorang muslim ketika menerima suatu berita atau informasi. Dalam konteks ayat 6 surah alHujurāt, terdapat kata naba', yang artinya berita. Berita (naba') yang dimaksud adalah menunjukkan informasi yang sangat penting. Jika ditelusuri ayat Alquran, padanan kata naba' dapat dijumpai pada surah al-Nabā' [78]: 2, yaitu:

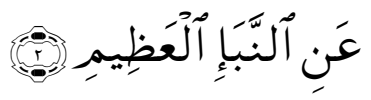

Artinya: Tentang berita yang besar. (QS. An-Nabā' [78] : 2)

Bila dilihat tafsir, maka sesungguhnya dijumpai perbedaan penafsiran terkait ayat ini. Ada yang menyebut al-naba' adalah berita hari kiamat dan berita tentang kenabian Muhammad saw. Penafsiran ini hampir merata disampaikan dalam kitab tafsir, baik itu tafsir bi al-ma'sūr maupun bi al-ra'yi. ${ }^{15}$ Agak berbeda dengan al-

${ }^{15}$ Muhammad bin Jāìr al-Ṭabāri, Jami’ al-Bayān at Ta’wīl al-Qur'ān, Juz 30 (Bairut: Darul Fikr, 1978), h. 3 . 
Marāghì yang menukil dari Ibn Abbas tentang penjelasan al-naba', yaitu terkait dengan berita turunya Alquran yang didustakan oleh sebahagian orang-orang Quraisy membenarkan dan sebahagian lagi mendustakannya, sehingga turunlah ayat di atas. ${ }^{16}$

Terlepas dari perbedaan pandangan mufassirin, hal terpenting yang perlu dipahami bahwa termasuk informasi yang sangat penting adalah diturunkannya Alquran sebagai sebuah kitab yang syarat di dalamnya termuat berita-berita besar. Bagi siapa yang mendalami maknanya secara serius, maka ia akan sampai kepada ketakjuban yang luar biasa. Pernyataan ini tidak hanya disampaikan oleh para pengkaji Islam, tetapi diakui juga oleh para kaum orientalis yang mengkaji Islam secara jujur. Annemarie Schimmel misalnya, mengakui,

Alquran yang dibawa oleh Muhammad saw yang agung, merupakan kitab agung yang tiada taranya dengan kitab-kitab lainnya. Gaya bahasanya sangat mengagumkan, tidak dapat ditiru, karena keindahan serta kekuatannya yang luar biasa. Teksnya tidak hanya berisi solusi untuk semua persoalan yang muncul di dunia, tetapi semakin dalam dikaji, semakin terungkaplah misteri-misteri gaib tentang Tuhan di dalamnya. ${ }^{17}$

Seiring dengan Schimel, lebih ditegaskan lagi bahwa Alquran bukan hanya sekedar berita biasa, tetapi sekaligus sebagai media Tuhan untuk mengkomunikasikan segala sesuatunya kepada hamba-hamba-Nya, karena isinya penuh dengan pemberitaan. Bagi orang-orang yang tercerahkan hatinya, dan tercerdaskan pikirannya, dapat dipastikan tidak akan meragukan setiap informasi yang terkandung dalam Alquran, karena isinya mendapat penjagaan dari Allah Swt. Mengutip bahasa Sayyid Qutb, "Alquran itu sangat indah dalam berkisah, bahkan model berkisahnya pun memiliki keistimewaan artistik luar biasa. ${ }^{18}$

Konkritnya, Alquran merupakan kitab yang berisi berita dan informasi luar biasa, dan itu disajikan sesuai dengan konteks kemasyarakatan. Oleh sebab itu, alMarāghi sebagaimana dijelaskan di atas, mengatakan Alquran merupakan berita luar biasa. Pemahaman terhadap berita (naba'), sangat relevan dengan pengertian berita yang dikemukkan oleh Dean M. Lyle Spencer sebagaimana dikutip Deddy Iskandar, yang menyatakan bahwa berita dapat didefinisikan sebagai setiap fakta yang akurat atau suatu ide yang dapat menarik perhatian bagi sejumlah besar pembaca. ${ }^{19}$ Dari sini dipahami, berita adalah suatu fakta, ide atau opini aktual yang menarik dan akurat

\footnotetext{
${ }^{16}$ Ahmad bin Mustafa al-Maraghi, Tafsir al-Marāgi, dalam CD Digital al-Maktabah al-Syamilah.

${ }^{17}$ Annemarie Schimmel, Introduction to Islam, terj. M. Chairul Annam (Jakarta: Inisiasi Press, 2003), h. 35-37.

${ }^{18}$ Sayyid Qutb, Indahnya Alquran Berkisah, terj. Fathurrahman Abdul Hamid (Jakarta: Gema Insani, 2004), h. 191.

${ }^{19}$ Deddy Iskandar Muda, Jurnalistik Televisi Menjadi Reporter Profesional (Bandung: Remaja Rosda Karya, 2005), h. 21. Jika diikuti logika berpikir pendefenisian berita yang dikemukakan Spencer, jelaslah sesungguhnya bahwa berita itu bersifat aktual, faktual, penting dan menarik. Jadi berita itu adalah sesuatu fakta menarik yang penting disampaikan untuk diketahui oleh orang lain, sehingga dengan pemberitaan informasi itu, orang menjadi tidak ragu-ragu terhadap sesuatu itu. Jadi di dalam berita itu, tidak boleh terdapat rekayasa, kebohongan atau hayalan yang bisa memungkinkan orang lain memberikan tafsir ganda (bersikap ambiguitas), yang menyebabkan lahirnya kesimpang siuran yang berefek pada tatanan masyarakat.
} 
serta dianggap penting bagi sejumlah orang, misalnya pembaca, pendengar maupun penonton. Jika dipakai logika kerja media massa atau jurnalistik, maka sesuatu itu dikatakan berita atau informasi jika memenuhi kriteria dasar, yaitu aktual, akurat, faktual, benar, lengkap, utuh, jelas-jernih, jujur-adil, berimbang, relevan, bermanfaat, etis dan sebagainya. Tidak sekadar informasi, tetapi berita itu disampaikan dalam kerangka memberikan informasi (to inform), mendidik (to educate), kontrol sosial (to control) dan menghibur ( to entertain). ${ }^{20}$

Konsep jurnalisme mengisyaratkan kewajiban etis pelaku pemberitaan untuk bertindak jujur, menyampaikan kebenaran, tidak melakukan manipulasi informasi, pemutarbalikan fakta, tetapi harus selalu mencari keakuratan dan validitas kebenaran yang diterima dan disampaikannya. Termasuk juga upaya untuk memastikan bahwa apa yang diberitakannya adalah suatu kebenaran perlu dilakukan check and recheck. Konfirmasi adalah upaya untuk mendapatkan keterangan langsung dari orang yang bersangkutan, sehingga pihak tersebut dapat menyampaikan benar tidaknya suatu informasi. Check and recheck adalah upaya untuk mendapatkan akurasi informasi, sehingga dapat disampaikan sesuai dengan kondisi yang sebenarnya.

Dalam kaitannya dengan berita dan peyampaian informasi, sumber normatif Islam, yaitu Alquran menganjurkan setiap orang untuk berkata benar, jujur dan sesuai dengan fakta. ${ }^{21}$ Pada ayat lainnya, Allah swt juga memerintahkan untuk menjauhi prasangka yang akan mendatangkan keraguan dan ketidak benaran. ${ }^{22}$ Kejujuran dan kebenaran merupakan dua hal yang mutlak dilakukan dalam pemberitaan untuk menghidari terjadinya fitnah atau adu domba yang dapat memunculkan konflik. Untuk membuktikan kebenaran suatu informasi, maka diperlukan sikap kehati-hatian dan tabayyun. Dengan demikian, pemberitaan dituntut agar lebih berorientasi pada pencerahan dan pencerdasan umat (knowledge society), sehingga terciptanya kebaikan, seperti pengembangan kepribadian menjadi lebih baik, peningkatan ilmu pengetahuan, persatuan umat dan sebagainya. Bukan sebaliknya, menjadi profokator menuju kemunduran dan perpecahan.

Ayat 6 surah al-Hujurāt tidak hanya tertuju pada kasus yang menjadi sabab nuzulnya ayat tersebut, yaitu al-Walid bin 'Uqbah yang membawa berita bohong kepada Nabi mengenai al-Haris, yang tidak mau membayar zakat dan mengancam akan membunuhnya. Lebih dari itu ayat ini menekankan kepada umat Islam untuk bersikap kritis terhadap pemberitaan yang disampaikan oleh orang fasik, apapun berita yang disampaikan. Masyarakat harus kritis dan melakukan tabayyun terhadap informasi yang diperolehnya. Dikatakan pula bahwa ayat ini tidak berkaitan langsung dengan masalah keagamaan, tetapi lebih merupakan pemberitaan yang berkaitan dengan

\footnotetext{
${ }^{20}$ Lihat, Dennis McQuail, Mass Communication Theory, terj. Agus Dharma dan Amiruddin Ram (Jakarta: Erlangga, 1994), h. 69-71. Lihat juga, Sutirman Eka Ardhana, Jurnalistik Dakwah (Yogyakarta: Pustaka Pelajar, 1995), h. 2.

${ }^{21}$ Lihat, Q.S. Al-Aḥzāb [33]:70. Jujur maksudnya adalah menginformasikan tentang sesuatu hal sesuai dengan faktanya. Kebenaran adalah menginformasikan sesuatu sesuai dengan kenyataan, mengarahkan kepada cara berfkir yang positif.

${ }^{22}$ Lihat, Q.S. Al-Hujurāt [49]:12.
} 
kehidupan kemasyarakatan, yang kalau tidak ditanggapi dengan hati-hati, maka dapat menimbulkan instabilitas dan disharmoni, bahkan dapat menimbulkan kekacauan dalam masyarakat. Disinilah pentingnya proses tabayyun terhadap suatu berita dan informasi, karena berita merupakan sesuatu yang bersifat aktual, faktual dan berorientasi kepada kepentingan dan kemaslahatan orang banyak. Karenanya, tabayyun sangat erat kaitannya dengan persoalan moral. ${ }^{23}$

Ditinjau dari sudut kajian ke-Islaman, moral ini lazim disebut dengan istilah akhlak, yaitu bentuk tunggal dari kata khuluq yang diartikan dengan budi pekerti, perangai, tingkah laku dan tabiat yang membuat seseorang menjadi istimewa. Akhlak dibagi kepada dua macam, yaitu akhlak terpuji (mahmūdah) dan akhlak tercela (mażmūmaḥ). ${ }^{24}$ Pribadi yang memiliki akhlak terpuji (maḥmūdah) dengan sendiri pasti akan berdampak dalam kehidupan sosialnya. Akhlak ini akan menjadi tuntutantuntutan yang akan terus hadir pada saat manusia berinteraksi dengan pihak lain. Perilaku dalam berinteraksi secara sosial dengan orang lain, jika dilandasi dengan moralitas tentulah akan membawa kepada kebaikan dalam kehidupan bersama.

Dalam kaitan itu, karena tabayyun erat kaitannya dengan moral, maka tabayyun tidak hanya berlaku bagi penerima berita, tetapi berlaku sekaligus bagi penyampai berita. Ketika seseorang ingin menyampaikan berita, maka sebelum berita tersebut disampaikan, harus dilakukan juga terlebih dahulu proses selektif dan kritis (tabayyun). Mengutip bahasa Farni Hadi, penyampaian berita dan informasi harus didasarkan kepada sifat amanah (terpercaya), siddiq (jujur), fatanah (cerdas), dan tabligh(menyampaikan). ${ }^{25}$ Sesungguhnya sifat ini relevan dengan tuntutan ideal bagi para penyampai berita. Sifat amanah yakni terpercaya karena memiliki integritas pribadi yang unggul. Sidiq diwujudkan dalam bentuk keterpihakan kepada kebenaran dan keadilan. Fatanah menuntut kemampuan intelektual dan rasionalitas, atau bisa dikatakan bijaksana dalam menyikapi situasi peristiwa. Tablighdapat dimaknai menyampaikan kebenaran melalui berbagai informasi kepada masyarakat. Dari sini

\footnotetext{
${ }^{23}$ Moral merupakan nilai-nilai atau tolok ukur bagi bagi seseorang atau sekelompok orang untuk menilai baik/buruk, benar/salah, atau menyangkut cara seseorang bertingkah laku dalam hubungannya dengan orang lain. Suatu perbuatan dipandang bermoral apabila sesuai dengan kebiasaan atau adat istiadat pada suatu masyarakat, karena perbuatan tersebut dinilai baik dan berguna oleh masyarakat bersangkutan. Kebalikan dari itu, perbuatan yang melanggar kebiasaan atau adat istiadat akan dinilai sebagai perbuatan yang amoral, yakni perbuatan yang tidak bermoral. Misalnya, jika berita itu bohong atau rekayasa, dan memungkinkan akan merugikan khalayak, maka berita itu tidak perlu diekspos. Sebaliknya, jika berita itu benar, maka kebenaran itu harus disampaikan sesuai dengan fakta-fakta yang ada.

${ }^{24}$ Ali Abdul Halim Mahmud, At Tarbiyah al-Khuluqiyah, Terj. Abdul Hayyie al-Kattani (Jakarta: Gema Insani Press, 2004), h. 26.

${ }^{25}$ Farni Hadi menyebut istilah ini sebagai propethic jurnalisme, yaitu suatu praktik jurnalisme yang yang didasarkan pada peneladanan akhlak Rasulullah saw., yakni menyampaikan berita yang bermanfaat untuk semua orang berdasarkan cinta sebagai ibadah kepada Allah swt.. Maka orang wartawan (pembawa berita) yang seperti ini menurut istilah Farni Hadi adalah orang yang tercerahkan (enlightened), orang yang terpilih (chosen), orang yang yakin(convidence), orang yang berkhidmat untuk berbuat (commited). Lihat, Farni Hadi, "Pembentukan Karakter Jurnalistik Kenabian dan Informasi Berkeadaban", Makalah dipersentasekan pada Acara Dakwah Annual Confrence (DACon) ke I, Universitas Islam Negeri Sunan Kalijaga, Yogyakarta, Nopember 2012. h. 3-4.
} 
tegas terlihat, bahwa berita dan pemberitaan itu, dilakukan dalam kerangka perbaikan masyarakat.

\section{Penutup}

Berdasarkan uraian yang telah dipaparkan di atas, maka dapat ditarik kesimpulan, bahwa turunnya surah al-Hujurāt ayat 6 paling tidak memberikan pengajaran kepada kaum muslimin

1. Pentingnya kehati-hatian dalam menerima informasi, sebab informasi sangat menentukan mekanisme pengambilan keputusan, dan bahkan entitas keputusan itu sendiri. Keputusan yang salah akan menyebabkan semua pihak merasa menyesal. Pihak pembuat keputusan merasa menyesal karena keputusannya itu menyebabkan dirinya menzalimi orang lain. Pihak yang menjadi korban pun tidak kalah sengsaranya mendapatkan perlakuan yang zalim. Maka jika ada informasi yang berasal dari seseorang yang integritas kepribadiannya diragukan, maka informasi yang disampaikannya harus diperiksa terlebih dahulu.

2. Perintah memeriksa dan menyeleksi informasi yang diungkapkan Alquran dalam kata fatabayyanu, dengan tegas memerintahkan kepada setiap orang untuk memeriksa dengan teliti, sebelum mengambil kesimpulan. Istilah jurnalistik perlu adanya chek and richek, atau konfirmasi informasi pada sumber-sumber yang lebih dipercayai, sehingga semakin yakin terhadap kebenaran informasi yang berkembang untuk dijadikan sebagai fakta. 



\section{DAFTAR PUSTAKA}

Ardhana, Sutirman Eka. Jurnalistik Dakwah. Yogyakarta: Pustaka Pelajar, 1995. Aṣ-Ṣabūni, Muhammad Āli. Terjemah Tafsir Ahkām. Surabaya: PT Bina Ilmu, 1987. Safwāt al-Tafāsir, Jilid III. Bairut: Maktabāt al Aṣriyah, 2011.

As-Syawkāni. Fath al-QadirJuz V. Beirut: Dār al-Fikr, tt.

Aț-Tabārì, Jamì' al-Bayān 'an Ta'wìl al-Qu'ān Juz XXVI.Beirut: Dār al-Fikr, 1405.

Hadi, Farni. "Pembentukan Karakter Jurnalistik Kenabian dan Informasi Berkeadaban", Makalah dipersentasekan pada Acara Dakwah Annual Confrence (DACon) ke I, Universitas Islam Negeri Sunan Kalijaga, Yogyakarta, Nopember 2012.

Hefni, Harjani. Komunikasi Islam. Jakarta: Kencana, 2001.

Kadir, Abdul. Pengenalan Sistem Informasi. Yogyakarta: Andi, 2003.

Kasiir, Ibnu. Tafsir Alqurān al- 'Ażīm Jilid IV. Damaskus: Dār al-Khair, 2006.

Maḥmūd, Āli Abdul Hālim. Al-Tarbiyah al-Khuluqiyah, Terj. Abdul Hayyie alKattani. Jakarta: Gema Insani Press, 2004.

Al-Maraghi, Ahmad bin Mustafa. Tafsir al-Marāgi, dalam CD Digital al-Maktabah alSyāmilah.

Muda, Deddy Iskandar. Jurnalistik Televisi Menjadi Reporter Profesional. Bandung: Remaja Rosda Karya, 2005.

Quthb, Sayyid. Tafsìr Fì Zilālil Qur'ān, Juz 10, terj. As'ad Yasin, dkk. Jakarta: Gema Insani, 2009. . Indahnya Alquran Berkisah, terj. Fathurrahman Abdul Hamid. Jakarta: Gema Insani, 2004.

Shihab, M. Quraish. Tafsir Al Misbāh Volume XIII. Jakarta: Lantera Hati, 2002.

Shaleh, Qamaruddin, Dkk. Asbābun Nuzūl; Latar Belakang Historis Turunnya AyatAyat al- Qur'an. Bandung: CV. Diponegoro, 2009.

Schimmel, Annemarie. Introduction to Islam, terj. M. Chairul Annam. Jakarta: Inisiasi Press, 2003.

Sutanta, Edhy. Sistem Informasi Manajemen. Yogyakarta: Graha Ilmu, 2003.

Wilson, TD. "Human Information Behavior" dalam Jurnal Information Science Research, Vol. 3 No. 2 tahun2000. 